\title{
Economic and Psychological Aspects of Importance of Real Madrid Brand in Marketing Communication
}

\author{
Daniela Petríková \\ Tatiana Soroková \\ Technical University in Kosice \\ Email: daniela.petrikova@tuke.sk, tatiana.sorokova@tuke.sk
}

Doi:10.5901/mjss.2015.v6n3p504

\begin{abstract}
This article discusses the importance of brands in marketing communications. Our objective is aimed to provide a perspective on the mark in terms of psychological and economic determinants of the success of the company in the market. Through the company Brand Finance data show the value of the world's 10 most valuable brands, compared to 2013 and 2014 year as the net present value of expected cash flows corresponding label. The article also presents the top 10 most valuable football clubs and more detailed analyzes chosen brand of football club Real Madrid and the organization that owns it. From several points of view we discuss the dynamics of the development of the brand, its financial value, logo, personality, colors, slogan, jingle and expansion in the market. We present a brief historical overview, current status, while most interesting element linked to the expansion of the brand across continents, to the Arab world, which is associated with the treatment team logo reflecting the cultural and religious traditions. Article presents a synthesis of psychological aspects and economic indicators at the level of analysis of the financial health of the organization, distribution of income, turnover, debt, team building and success in the global market.
\end{abstract}

Keywords: financial management; EBITDA; brand; marketing communications; Real Madrid;

\section{Introduction}

The latest development in entrepreneurial and corporate environment has shown that corporations are push to increase the emphasis on usage of marketing methods in order to increase profitability. This unique trend of concentrated changes has caused the success or the failure of product realization to be established by its brand and brand awareness.

The sporting activities are the proof that also this part of social life has a potential to be not just the activity for free time and entertainment for wider social groups; but it has the opportunity to become the main profit generating sector for corporation. One the example of connections between economy and sport is the widely spread favorability of the football (in American English football refer to soccer). The world globalization trend is encouraging and in the same time enabling the creation of big and strong brands which based on theirs global networks of supporters is able to achieve significant economic success.

The sporting and economic triumphs of various football clubs such as FC Barcelona, Manchester United, Real Madrid and others, prove that those clubs are able to attract more and more investors and numerous sponsors. By selecting the brand of popular clubs the consumers are presenting their statements of their personal ideologies and they are expressing it by using the symbols of selected brands. Based on this we can conclude that brand itself is a source of the economic strength which is measurable by the level of revenues - usually in million Euros.

\section{Value of the Brand}

In general, based on the current economic dynamics a brand and its value is one of the most significant attributes for success. A perception of particular brand differs, "A brand price is established by the desire of a buyer to own" (Olins, 2009, p. 202), "A value of the brand represents a group of associations and attitudes towards brand in overall value chain...". (Prïbová, 14, p. 29) The term 'brand value' is in general defined by its financial value, although its evaluation due to its character as an intangible asset can be difficult but not impossible; which have been proven in respect to various brands and by changes of its ownership structures.

The numbers of companies such as Forbes, Interband or Brand Finance are focused on creating the ranking of 
various types of brands based on their market value. An advisory firm, Brand Finance has been publishing ranking of the most valuable brands for last couple of years. In general, the ranking is created based on specific financial information and detailed information about revenues. This approach differs from those which are focused on measuring and ranking the strength of brands. The ranking creation focused on measuring the strength of the brands is considering broader spectrum of financial indicators, such as net margin, average income per customer, marketing and advertisement costs or other qualitative indicators such as influence of a brand and customers' loyalty.

The Table 1 below shows the most valuable brands form global perspective based on the methodology published by Brand Finance for the year 2014. Brand Finance considers into this ranking one unique attribute which focuses on costs which would have occurred if some entity would decide to use this brand and it would genera present and future expected revenue. (Brand finance, 2014)

Table 1. 10 brands with the highest value in 2014

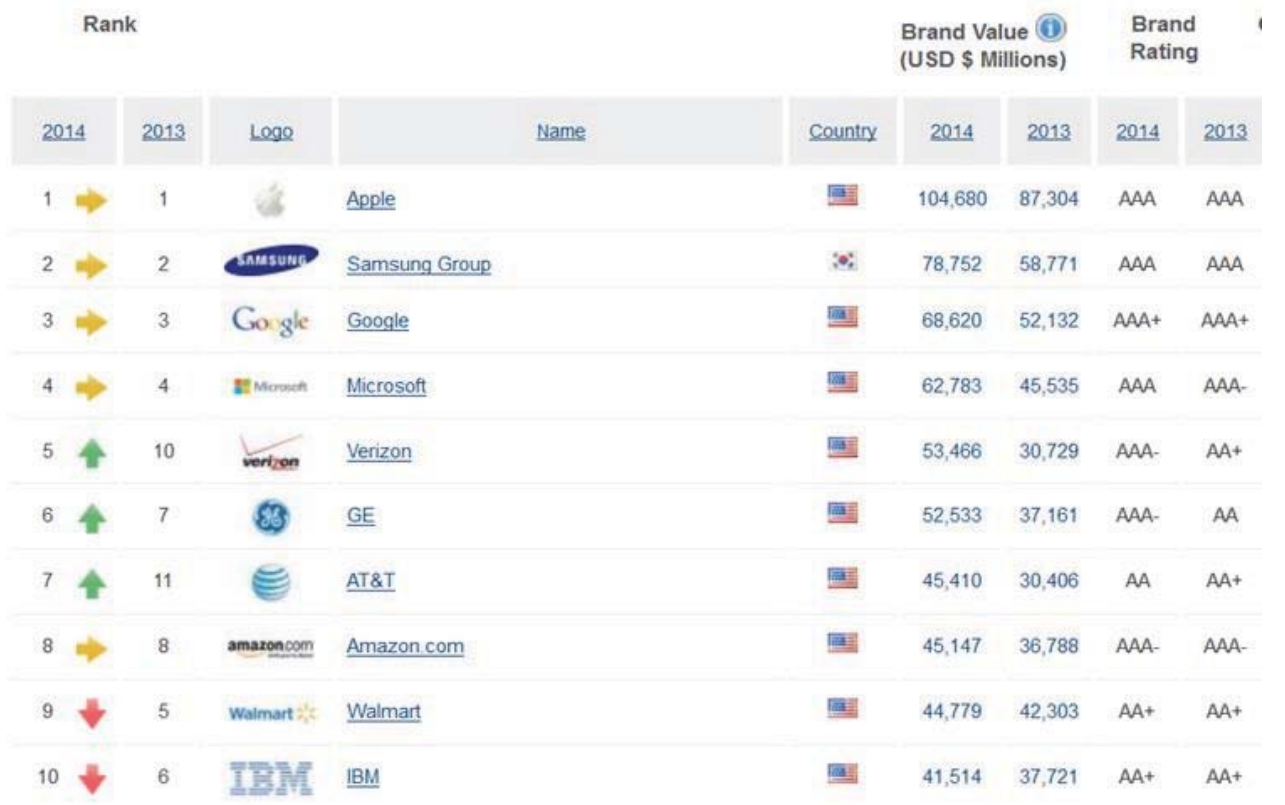

Source: (Brand finance, Global 500, 2014)

The increasing importance of building the brand is supported by the facts which in year 1962 showed that average company had $62 \%$ of value tied in physical assets. This number had been decreasing ever since and over next couple of decades in 1992 it reached the level of 32\% and in year 2000 its level was just 20\%. (Sasko, 2010) The presented trends are being supported by various researches conducted at the companies from USA and Great Britain. The results show that about $80 \%$ of values of companies are represented by intangible assets, although the companies' brands represent at least $20 \%$ of that value. (McDonald, 2009)

The high brand value provides its owner various advantages such as loyal customers who are attracted by the brand and this can be accompanied by price increases from owner perspective. The high prices and brand reputation are influential factors focused on customers with certain psychological site to it and it acts as a guarantor of quality and success. A psychological success lies with the consumer willingness to pay more for something which has proven to be useful and favorable and has as well very positive ratings and broad affectation for consumers markets.

\section{Analysis of the Real Madrid Brand}

Real Madrid was founded on 6th March 1902 (at that time as "Madrid Club de Fútbol") under a president Julian Palacios. In 1912, club had 450 members and from their financial contributions it was possible to build and consequently move club activities into the first official football stadium named O'Donnel Stadium, which was the first fenced stadium at that time in Spain. The main ambition of the Real Madrid Club it was to become the most famous club from global perspective. The 
founders came with a revolutionary idea which helped to form history of the club and it can be considered as the first marketing move in history of Real Madrid Club. On 17th of May 1902, shortly after the club had been founded the first football tournament had been organized in honor of the coronation of King Alfonso XIII.. This was a unique opportunity to attract attention and new supporters. The tournament visitors and supporters were expecting to see royal family in live and the opportunity to cheer with royal family for the same club created opportunity for the club to generate high revenue from highly priced tickets which helped in further club development efforts. The final tournament results were not so satisfying from sporting side of thing where Real Madrid failed to succeed in competition of F.C. Barcelona and Vizcaya (current Athletic Bilbao). The other side of the tournament had provided the club with strong royal and government connections which resulted in renaming the club to "Real Madrid Club de Fútbol" in 1920. From this year onwards, the club has been psychologically different from other club, which has been pointed out by its excellence, uniqueness and character. (Bourne, 2014)

\subsection{Business activities}

At a football pitch the Real Madrid creates complex product which has extraordinary good sales. The football matches are represented as an individual product which purpose is "being sold" and at the same time it is a foundation and starting point for other economic activities of the club on the market. The sporting activities itself are not the only one domain of the sport and organizations conducting business activities in this sector. In order to achieve the highest level of success a diversification of business activities is necessary. Based on these, currently, the penetration of the business styles into the sport is more visible and significant and the essential commercialization has penetrated every sporting sector.

Based on the top notch marketing and revenues from commercial activities the Real Madrid has become even more popular over last years. The biggest part of the club income is generated via TV rights, advertisements on the football jerseys and by the numerous sponsorships which are achieved by the most lucrative business deals. One of the psychological phenomena is an image of football players and based on their personalities, football popularity and performance are generating enormous income for the club. The pure fact that Real Madrid at this moment has most of the players with the highest value and strong income generating potential; those facts in combination with psychological image put Real Madrid at the top of the ranking table of the most valuable brands (Table 2).

Table 2. TOP 10 most valuable football brands in 2014

\begin{tabular}{|c|c|c|c|c|c|c|c|c|}
\hline \multicolumn{4}{|c|}{ Rank } & \multicolumn{3}{|c|}{$\begin{array}{l}\text { Brand Value (i) } \\
\text { (USD S Millions) }\end{array}$} & \multicolumn{2}{|c|}{$\begin{array}{l}\text { Brand } \\
\text { Rating }\end{array}$} \\
\hline 2014 & 2013 & Loge & Name & Country & 2014 & 2013 & 2014 & 2013 \\
\hline $1 \Rightarrow$ & 1 & $\theta$ & Bayern Munich & 国 & 896 & 860 & AAA & AAA \\
\hline 2 霖 & 3 & (3) & Real Madrid & $=$ & 768 & 621 & AaA+ & AAA+ \\
\hline $3 \star$ & 2 & 0 & Manchester United & II & 739 & 837 & AAA & AAA+ \\
\hline $4 \Rightarrow$ & 4 & 慗 & EC Barcelona & I & 622 & 572 & AAA+ & AAA \\
\hline 5 슬 & 8 & $=$ & Manchester City & Hit & 510 & 332 & AAA. & AA. \\
\hline $6 \Rightarrow$ & 6 & $\theta$ & Arsenal & 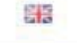 & 505 & 410 & AAA. & AA+ \\
\hline $7 \downarrow$ & 5 & (1) & chelsea & 看 & 502 & 418 & AAA. & AA \\
\hline $8 \geqslant$ & 7 & 悤 & Liverpool & Elat & 469 & 361 & AAA- & AA \\
\hline 9 슬 & 10 & 8 & Borussia Dortmund & 回 & 327 & 260 & AAA- & AA \\
\hline 10 슨 & 24 & e & Paris Saint-Germain FC & 10 & 324 & 85 & AAA- & At $^{+}-(-1)$ \\
\hline
\end{tabular}

Source: (Brand finance, The Brand Finance Football, 2014)

Real Madrid sells its own products in their own shops and vie its distribution and marketing is realized via numerous distribution channels, such as internet, TV or radio. The other very important components of the club income are advertisement objects, jerseys, various shows and events (football matches, business meetings, festivals, celebrations 
etc.). For instance, Real Madrid yearly jersey sales are around a one and half million jerseys where the price of one jersey is on average about 81 Euros. Another statement of the income generating strength of the Real Madrid club brand is the Addidas shop sales at the stadium. This shop is the most profitable one from the global perspective and on average it has yearly around 2 million shoppers. (Real Madrid news, 2013)

\subsection{Characteristics of the Real Madrid brand}

In 1920, the King of Spain gave the club permission to used new name "Real Madrid Club de Fútbol" and from this point this name became official name of the Real Madrid football club. Real Madrid is owner of various forms of its name which are presented as brands, such as Realmadrid.com, MyMadrid, eMadridista, Realmadrid. Those brands purpose is to market and represent vast range of club's products and services which are offered by the club (for instance advertisement objects, clothes, communication via computer networks). (Ditte, 2012) Other parts of this brand are logo, players and other personnel, slogan and anthem.

The Real Madrid logo has gone through various changes since the club foundation (see Picture 1). One of the most visible changes was omission of the crown from the logo which was executed in 1931, in time of so called "second republic". The work "real" had been stripped from a title of the club and purple strip had been added to the club logo, which represented a region in Spain call Castile - region of Madrid City. Two years after the civil war had ended the Real Madrid had re-designed the logo by adding the royal crown, although the purple strip has remained there until nowadays. Psychological changes of the logo were dynamic changes and perception of ne society influences and other political changes in the country.

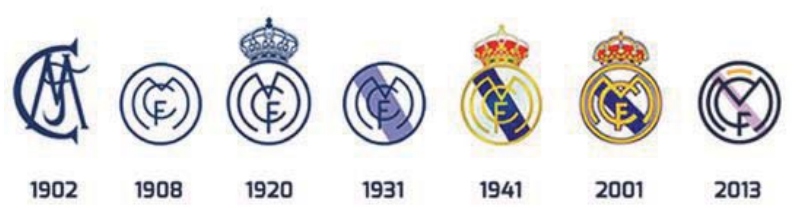

Figure 1. Historical changes of the Real Madrid logo. Source: (Real Madrid Football Club Logo History, 2014)

For the sport club, it is characteristic to present themselves' by their players and managers. Due to the fact that Real Madrid brand present itself as synonymous of strength, success or winning, therefore the management is very much focused on rigorous selection of the personnel which are often in public eye and should be sub-instrument in achieving set goals. During the history of the club; there has been many instances when club has focused on attracting world class players with additional exceptional qualities (those beside football skills), such as Di Stéfano, Zidane, Ronaldo, Beckham, Kaká or C. Ronaldo. (Soccerbible, 2012) Those qualities were focused on securing the great sporting achievements together with positive perception of the club from public which was certain guarantee of the value and this was consequently transferred into the other business activities.

The major color of Real Madrid from the beginning it has been color white and the inspiration for this color was taken from the club Corinthians FC. Based on this color the nickname 'Los merengues' was created which in translation means 'white'. In general, the white color represents elegance and grandeur and therefore the club is aiming to maintain its activities in this spirit. Another colors which are being presented as the club colors are golden, red and blue. Those colors are presented in club's logo and it represents a symbol of royal power.

Real Madrid, as a trademark brand, doesn't have any official or registered slogans which are so common amongst other brands. For certain type of slogan can be considered a Spanish words connection "Hala Madrid" what in translation means "Go Madrid" or "Forward Madrid". These words connection or slogan is widely used by fans, club executives or club supporters expressing its support towards club.

Similarly to clubs' personnel and slogans, the sport sector is specific as well in term s of creating the own anthem. A purpose of club anthems is to increase awareness about brands which is as well being presented in media but the main purpose of an anthem is to increase cohesion of fans and its relations toward particular brand.

Whereas, the purpose of a name, logo and club popular personnel is to present itself as a trademark(-s) primary used for differentiation in the market based on color, slogan and anthem and all this factors act as unique identifier from the psychological perspective. 


\subsection{Consumer market}

A success on the market is determined by the ability of company to explore and conquer a share of the market. Size of the market is determinant only if the company can explore this opportunity. The general economy law states that the bigger share of the market can company achieve the more profitable company will become.

Activity of any sport club is mostly determined by the size of particular market the club is operating in and by its number of fans, fan clubs and overall popularity amongst consumers. Consumer markets for realization of Real Madrid products can be groped down into four main segments. The segmentation of the market is based on geographical location, such as European market, Asian market, North American market and African market. Mentioned markets are targeted via different types of marketing strategies and activities mainly due to the character of those markets and its consumers.

According to study of the agency Sport+Markt from 2010, Real Madrid is a club with second biggest fan base in Europe. This strong position is mostly based on appearances during regular football season in Spain and based on appearances in the most prestigious football club competition on the World - The Champions League, which is being played on the European continent (Keselak,2010)

The football is the most popular sport in Europe without any close competition but in the North America, soccer has to 'fight' for its place on the field of popularity with the most popular sport which is American Football. Currently, a dominance of traditionally very strong sports in North America has started to weaken, which is due to several factors.

Firstly, this is mainly due to the fact that American TV stations have started to buy sporting rights for broadcasting the European football leagues and modern social and digital media have enabled American fans to establish and maintain contact with foreign leagues, clubs and players. Secondly, the biggest football clubs, including Real Madrid, are in the process of building the massive marketing structure which has global reach far beyond the local markets. Another factor is that continuously growing Hispano-American minority is supporting football and football loyalty has been growing cross the whole American market. Real Madrid applies flexible marketing strategy and its reactions are changing based on the changing preferences of football fans on the American market which helps to increase the fan based overseas. As mentioned previously, the constantly growing population of Hispano-Americans helps to strength market positions for football clubs. Natural inclination of Hispano-Americans towards Spanish language is obvious and this is one of the factors why this minority is primary focused on football clubs from Spain. According to government survey conducted in 2011 in the USA, there are more than 34 million Americans older than 5 years who are speaking Spanish which represents $12.3 \%$ of total American population older than 5 years. (Gonzalez-BARRERA, 2013)

Asian market - from the perspective of its population size has significant enticement for any organization which is basically in 'sales' business. In the geographical location, Real Madrid presents itself mostly during off-season matches. The new trend in Spanish league considering Asian market is customization of airing times for live matches in order to attract fans and viewers from other side of the globe from distinctively different time zones. One of the main marketing strategies of Real Madrid is based on pre-seasonal tournaments and matches which are being played before or after the main season of its home league. From Real Madrid perspective this activity is mostly focused on American and Asian market.

Arabic market - this market is the newest one in global expansion plans for Real Madrid and the ambition to expand consumer market was presented in March 2012. Real Madrid Club together with emirates government RasalKhaimah announced commencement of its mutual project named 'Real Madrid Resort Island'. This Resort Island will be thematic park and tourist complex located in the north of United Arab Emirates and it will operate under the Real Madrid brand. According to project, the park should include amusement park, the first open stadium next to sea, the first holographic football performances, Real Madrid museum, numerous sport activities, sport port, residential development, luxury hotels, regeneration centers with wellness oriented even on most demanding clients. This project should be completed by the year 2015 and it should be the entry gate for mutual African-Asian market. (Transfermarkt, 2013) The location has been selected based on two factors; two billion potential visitors market in range of 4 hours flight and it should attract (also in terms of capacity) one million visitors in its first year. The current president of Real Madrid Club, Florentino Pérez announced after the project presentation: 'Connection of Real Madrid with Emirates is a synonym of professionalism, success and it strengths the Real Madrid brand and it as well increases the brand awareness. All our allies will be very proud of the Real Madrid Resort'. This statement had been followed by statement from Sheikh Khalid bin Faisal bin Sultan Al Qassimi 'It is exciting project developed in cooperation with the global brand. We are very proud that Real Madrid has chosen Emirates and we appreciate the vision and we have million reasons to be optimistic about this project. This will change the United Arab Emirates and we are ready to welcome a progress and millions of visitors who will come to visit 'Real Madrid Resort Island'. (Ditte, 2012) 
The brand expansion cross the continents could be an effective tool for global marketing campaign which has started to be implemented by Real Madrid. Because of the Real Madrid Resort Island project, Real Madrid agreed to implement some extraordinary changes towards its logo by eliminating the cross from the royal crown (Picture 2). (Real Madrid buang tanda salib pada logo, 2012)
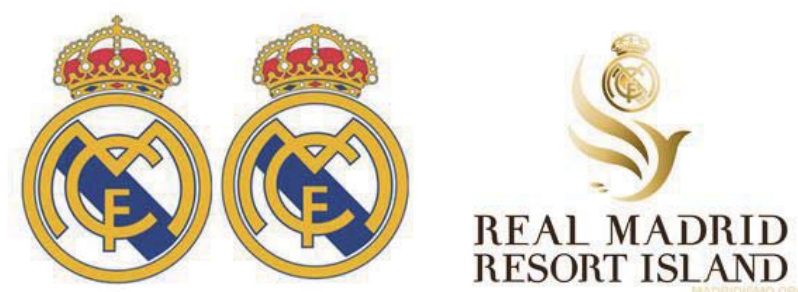

Figure 2. Differences between official Real Madrid logo (left - see top of the crown), the logo used for the Real Madrid Resort Island project (in the middle) and the official Real Madrid Resort Island logo (right). Source: (Real Madrid buang tanda salib pada logo, 2012), (Madridismo, 2012)

This decision had been considered as a positive concession towards non-Christian regions where the project will be located and significance of this decision had been amplified by the fact that Spain is traditionally very strongly devoted Christian country.

\subsection{Internet, radio, TV and social networks}

Currently during the busy league season which is exceptionally demanding in Europe, Real Madrid uses for further expansion on new markets mostly modern mass distribution channels, such as internet, radio and TV. Significant moved towards further expansion was the creation of the more fans friendly club webpage. The need from the psychological point of view for this step was so strong that club recognized necessity to address wide audience with specialized pages in different languages under local domains. For instance, pages have been created in Spanish, English and Arabic language (www.realmadrid-arabia.com), Japanese (local domain - www.realmadrid.jp) and in 2012 it was expanded by Indonesian language (local domain - www.realmadrid.co.id). Further to expansion, it proved to be very helpful to create the own TV channel which has been done and now for fans is available Realmadrid TV. This channel is being broadcasted 24 hours daily since 2004 and it includes news, interesting details, matches, trainings and similar activities. The channel is being broadcasted on non-coded (unlocked) waves in English and Spanish languages. In 2008, as the first club, Real Madrid had created radio channel which offers inside information about players, club and daily developments and events.

Another very popular way for strengthening and expanding of the fan base is via social networks. The club has selected Facebook, Google+, Youtube and Twitter as main social network channels for active communication with its users.

One of the proofs of the strength of Real Madrid is information from the report of 'League of professional football at the social networks'. This report is being compiled by IAB Spain which is focused on digital marketing in cooperation with marketing agency Ontwice. The report from June 2011 stated that advertisement value of the official webpage of Real Madrid is more than 30 Million Euros, whereas the value of Barcelona FC is approximately 13 Million Euros. In comparison, the fan base of Barcelona FC on the Facebook was at that time 18 million fans whereas the Real Madrid fan base was 16 million fans. (My Marketing World, 2012) It is almost impossible to measure the impact of marketing strategies due to its dynamical character, however increasing brand awareness on the social networks leads potentially to higher sales and to higher market share. (Vejačka, 2012)

The most recent survey conducted by company Perfect which was published two days prior the beginning of the World Cup 2014 in Brazil showed that Real Madrid, Manchester United and Barcelona FC are amongst the best football clubs from social media and webpage optimalization perspectives. (Bourne, 2014), (Brand Perfect: Goal!, 2014)

\subsection{Value of the Real Madrid brand}

The value of Real Madrid brand is being presented by the official report published by the global consultancy firm Brand 
Finance which is mainly focused on brand evaluations. This consultancy firm has been publishing the ranking of the most valuable club brands since 2005. Historical development of the Real Madrid brand value is being presented by the Graph 1 since 2005 (excluding data for 2008 which were not publicly available). Brand Finance conducts brand evaluations based on methodology known as 'Royalty relief'. This methodology considers clubs as not the owners of the brand but as third parties who are required to purchase licensing in order to use a particular brand.

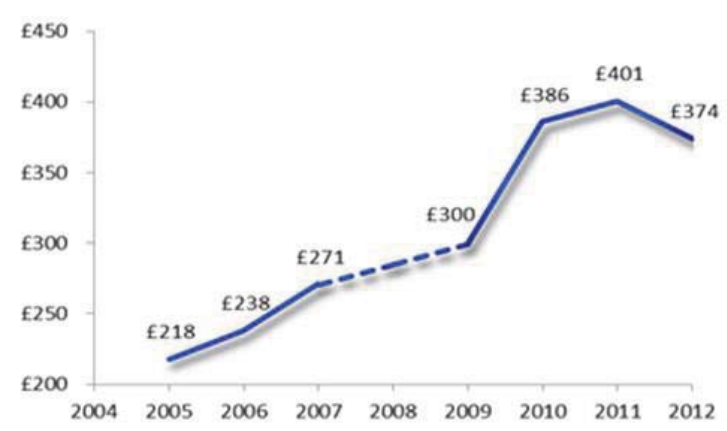

Figure 3. Historical development of the Real Madrid brand value (mil. £).Source: (Val'ovský, 2012)

Based on the historical development of the Real Madrid brand we can conclude that club manages to achieve continuous growth of its value till 2011. Between year 2005 and 2011, Real Madrid managed to achieve the most valuable brand status in years 2005, 2006, 2007 and 2010. For instance, in 2009 this status was claimed by Manchester United, although the year later this status was claimed again by Real Madrid with brand value of 386 million $£$ which represented $29 \%$ year to year growth. This growth had been achieved by high profile player transfers, such as C. Ronaldo, Kaká and Benzema. Based on these transfers, the club has started a new area under president Florentino Pérez called 'Galácticos' which attracted massive interest from global media. However, the sport achievements lacked behind those projected ones and the completed satisfaction was not achieved. In year 2011, it had been third year in a row that Real Madrid did not win the Spanish League and had not won the Champions League in almost a decade. These dissatisfactions and lack of sporting achievements caused the decrease in brand value despite the revenue growth. The brand value growth had been only 3.9\% which meant that Real Madrid was surpassed by Manchester United as the most valuable brand. The worst ranking for Real Madrid was in 2012 when the club fell to third place in ranking table behind Manchester United and Bayern Munchen. The weak state of Spanish economy pushed the values of all Spanish clubs toward negative growth, where Real Madrid brand value fell to 374 million $£$ which represented $7 \%$ drop in 2012 from the value of 401 million £ in year 2011. (Val'ovský, 2012)

Considering the current economic situation within European economies more innovative approach need to broad forward in order to improve a performance of individual countries and its business subjects. The fact that all of the global economies are facing zero or minimal economic growth has impact on all industries and sub-sectors. Over last year or so, there has been some positive information about performance improvements, although the feeling of extended crisis is still upon us including public as well as private sectors. (Szabo, 2013) The Spanish economy has not improved sufficiently to wipe the dip it took 5 years ago and the importance of foreign markets and fans is currently even more significant for domestic clubs and especially Real Madrid.

\subsection{Building of the team and successes}

Real Madrid brand is the unsplittable part of 'madridism' conception. The basic principle of this conception is appraising the superiority and winning at any cost. The club is personificating a Spanish sporting approach 'machacar' which means 'to crush (without mercy)' and therefore it is very important for a brand to maintain each of its conceptions. In case of Real Madrid, this idea of being superior is express via its players; specifically by its expensive world class players which should ensure that club will achieve required results with unique flavor of elegance which is specific for the brand of this organization.

Florentino Pérez had begun during years 2000 and 2006 the strategy of assembling the team from so called 'Galácticos', and this approach has been maintained in this second term as club president. Immediately in season 2009/2010 the massive reconstruction of the squad started when 13 players left the club in value of 87.5 million Euros and 9 new players came in worth of 257.4 million Euros, although $62 \%$ of this amount was due to incoming transfer for $\mathrm{C}$. 
Ronaldo and Kaká. Specifically those two players should be at that time the main engine behind sporting results and prestige for Real Madrid brand. Over next two seasons the expenditure for transfers decreased, although it still exceed the income from sold players, where in season 2010/2011 income was just 10 million Euros and expenditure 93 million Euros, and in season 2011/2012 income was 8 million Euros and expenditure 55 million Euros. (Transfermarkt, 2013) Graph 6 shows above mentioned expenditures, income and difference from sold and bought players.

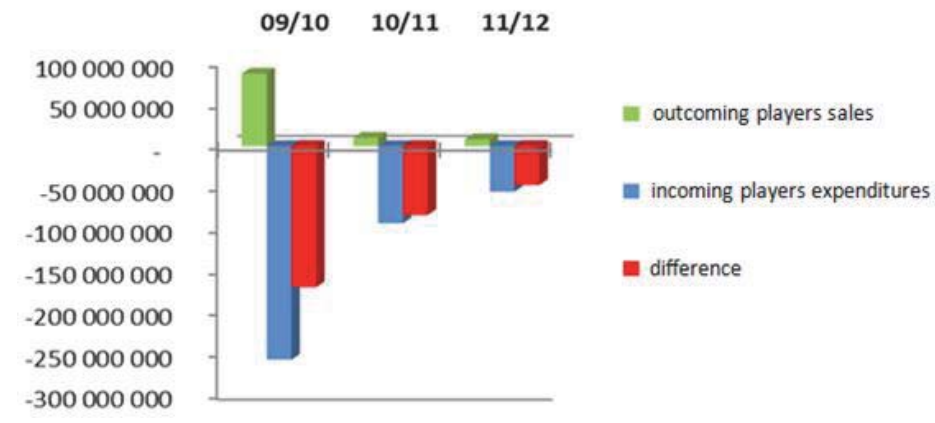

Figure 4. Comparison of the players transfers fees. Source: (Val'ovský, 2012)

The Real Madrid approach towards building its brand based on buying profit generating players has been reflected on the ranking of the top ten most expensive players' transfers, where Real Madrid has five players, such as Cristiano Ronaldo, Kaká, Zinedine Zidane, Luis Figo a Ronaldo de Lima. (Szabo, 2013) The attractive game play is psychological aspect which has capabilities to help a football brand to ensure strong support and viewers; however it isn't a guarantee for any future or end of season success.

\subsection{Financial background}

In general, strong brand requires solid financial base and structure based on which can launch any progression efforts. Strong financial position enables football clubs to buy expensive players, launch various projects and conduct different activities. Those activities conducted by clubs then have psychological effects on consumers and fans which help expand a reach of the brand. Revenues and level of debt during the certain period of time enable clubs to create trustworthy signals at the side of consumers, investors, fans, sponsors and those signals do influence position towards brand from economic perspective. According to report from Deloitte Football Money League in season 2004/2005 Real Madrid had started its 8 years long run as top brand from economic perspective. Graph 3 shows the revenues of Real Madrid which had been achieved over its most successful seasons from season 2004/2005 to 2011/2012. An average yearly revenues growth has been capped at around $9.4 \%$ and in the last season Real Madrid managed to generate revenues of more than 500 million Euros which has not been achieved yet by any other elite sports club from global perspective. (Realmadrid. Annual Report 11/12, 2012)

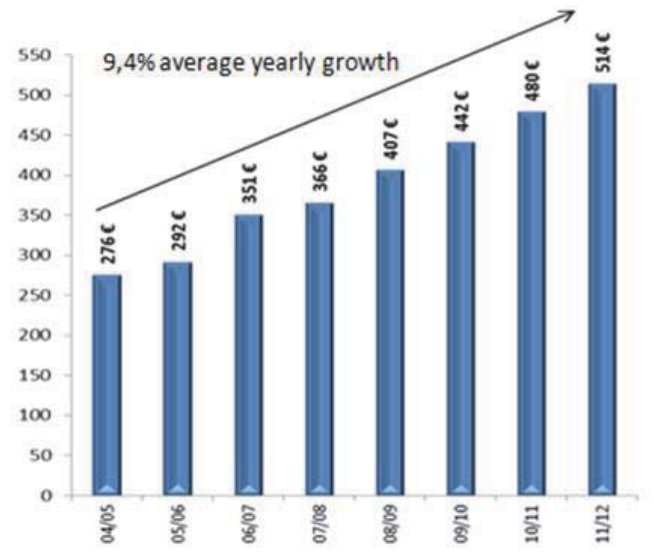

Figure 5. Revenues of Real Madrid. Source: (Realmadrid. Annual Report 11/12, 2012) 
In general, football club revenues come from various activities. According to report from Deloitte, football clubs generate revenues from three main activities, such as income from TV rights, commercial activities and from match days. This segmentation of the revenues is presented by Graph 4. TV rights activity includes mostly the rights given to TV stations for broadcasting its football matches which is negotiated separately for different market segments. Over the years income from all three main activities had achieved growing trend and from season 2007/2008 Real Madrid income from TV rights exceeded other two revenues generating activities due to the new contract with company Mediapro in value of 1.1 billion Euros with contract length of seven football seasons. Other revenue generating activities are generally focused on sponsoring, merchandising and licensing. These revenues were the biggest ones in seasons from 2004/2005 until 2006/2007. This period of time is well known as the first term of 'Galácticos' project and during those seasons the main frame of Real Madrid squad has been built from players like Beckham, Zidane and Ronaldo. This fact and squad structure had allowed the club to generate significant revenues from licensing and merchandising. The revenues from match days are mostly generated by ticket sales and stadium services. Over those seasons the stadium improvements had been implemented numerous times and main changes were capacity expansion and conformability improvements. These activities helped club to generate additional income from same fixed assets and therefore the utilization of clubs' assets had been improved as well. The other change was noted as increase in ticket pricings which could be achieved due to expansion of provided services and its quality. During season 2012/2013 revenues from match days were in value of 119 million Euros (23\% of total income), income from commercial activities 211.6 million Euros (41\% of total income) and revenues from TV rights were 188.3 million Euros (36\% of total income). (Deloitte: Football Money League, 2014)

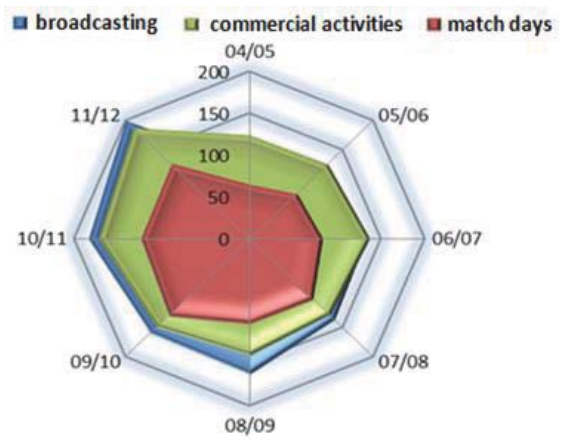

Figure 6. The Real Madrid income structure. Source: (Val'ovský, 2012)

The level of income had been the main driver behind an affordability of the club towards new transfers (and other employees). Players' wages are very important negotiation tool for club management during transfer's season and this is strong psychological factor of the brand. The value for transfers cannot be according to 'fair-play' UEFA regulation more than $70 \%$ of club's income. Table 3 shows salaries, sales and ration indicator of these two metrics. This ratio indicator remained mostly same over the years with year to year change around 1\%; however the exception was season $2009 / 2010$.

Table 3. Salaries, sales and ratio indicator of salaries/sales for Real Madrid

\begin{tabular}{|l|c|c|c|c|c|c|c|c|}
\hline & $\mathbf{0 4 / 0 5}$ & $\mathbf{0 5 / 0 6}$ & $\mathbf{0 6 / 0 7}$ & $\mathbf{0 7 / 0 8}$ & $\mathbf{0 8 / 0 9}$ & $\mathbf{0 9 / 1 0}$ & $\mathbf{1 0 / 1 1}$ & $\mathbf{1 1 / 1 2}$ \\
\hline Salaries (mil. €) & 144 & 137 & 168 & 168 & 187 & 190 & 216 & 236 \\
\hline Sales (mil. €) & 276 & 292 & 351 & 366 & 407 & 442 & 480 & 514 \\
\hline Salaries/Sales & $52 \%$ & $47 \%$ & $48 \%$ & $46 \%$ & $46 \%$ & $43 \%$ & $45 \%$ & $46 \%$ \\
\hline
\end{tabular}

Source: compiled by authors (Realmadrid. Annual Report 11/12, 2012)

The presented ratio of salaries and sales is very often used as an expression of effectivity of the club which is very important while evaluating the financial future of the club. If the ratio value is low it means that club has strong precondition to achieve strong financial position.

Another factor which expresses the financial stability of the Real Madrid brand is level of debt. We had compared four seasons from 2008/2009 until 2011/2012. During these seasons financial statements showed that club had taken on 
various bank loans and this was a visible change in comparison to previous seasons. The club had been 'loan free' establishment since 2002 until the 2008/2009 season. Table 4 shows the calculation of the debt according to the UEFA methodology based on financial 'fair-play' directive and according to internal Real Madrid financial statements. The methodology of debt calculation from Real Madrid side differs in following inclusions: besides general bank loans (debts) it includes transfer payables/receivables, investment payables focused on stadium and training centers and other buybacks from licensing.

Table 4. Calculation and development of the Real Madrid debt (thousands $€$ )

\begin{tabular}{|l|c|c|c|c|}
\hline & $\mathbf{0 8 / 0 9}$ & $\mathbf{0 9 / 1 0}$ & $\mathbf{1 0 / 1 1}$ & $\mathbf{1 1 / 1 2}$ \\
\hline 1. Bank loans & 149706 & 166517 & 145762 & 143309 \\
\hline 2. Cash and cash equivalents & 111619 & 92731 & 97769 & 113237 \\
\hline 3. Net bank debt (2-1) & 38087 & 73786 & 47993 & 30072 \\
\hline 4. Transfer payables & 228684 & 175927 & 125646 & 90354 \\
\hline 5. Transfer receivables & 17968 & 64897 & 49456 & 35095 \\
\hline 6. Transfer fees - difference (4-5) & 210716 & 111030 & 76190 & 55259 \\
\hline 7. Debt according to UEFA (3+6) & 248803 & 184816 & 124183 & 85331 \\
\hline 8. Other creditors & 80894 & 59749 & 45538 & 39327 \\
\hline 9. Debt according to Real Madrid (3+6+8) & 329697 & 244565 & 169721 & 124658 \\
\hline
\end{tabular}

Source: compiled by authors (Realmadrid. Annual Report 11/12, 2012), (Realmadrid. Annual Report 9/1, 2010)

According to Table 4, a level of the debt (bank loans) based on both methods was more or less same and the biggest debt was in season 2008/2009. This was mainly due to players' transfers for the season 2009/2010. Over next four seasons based on the increase in income Real Madrid had managed to lower its debt by $65.7 \%$ (according to UEFA) or respectively by $62.19 \%$ (according to Real Madrid).

In order to evaluate the firm's ability to repay debt a financial indicator Debt/EBITDA is often used. This indicators show the ratio of Debt to Earnings (before interest, tax, depreciation and amortization) and the lower the indicator value is the better it is for company. The value of Debt/EBITDA shows number of years in which would company repays its debt according to current level of income. This indicator is presented in Table 5.

Table 5. Development of EBITDA and calculation of the indicator Debt/EBITDA

\begin{tabular}{|l|c|c|c|c|}
\hline & $\mathbf{0 8 / 0 9}$ & $\mathbf{0 9 / 1 0}$ & $\mathbf{1 0 / 1 1}$ & $\mathbf{1 1 / 1 2}$ \\
\hline EBITDA (million $€$ ) & 105 & 146 & 151 & 154 \\
\hline Debt (UEFA)/EBITDA & 2,4 & 1,3 & 0,8 & 0,6 \\
\hline Debt (Real Madrid)/EBITDA & 3,1 & 1,7 & 1,1 & 0,8 \\
\hline
\end{tabular}

Source: compiled by authors (Realmadrid. Annual Report 11/12, 2012), (Realmadrid. Annual Report 9/1, 2010)

Financial situation of Real Madrid is reasonably satisfying which is supported by its ability to repay outstanding debt. Debt reduction is influenced (positively) by yearly growth of the clubs EBITDA which helps to create positive evaluation of the club from financial institutions standpoint and the overall position of Real Madrid brand.

\section{Conclusion}

Based on the presented analysis of economic and psychological aspects of brand significance in marketing communication we had focused our interest on evaluation of brand in relation to organizational success on the market. The brand enables company to motivationally and psychologically communicate with customers and via this communication company achieve its sales and new markets expansions. Trademark and logo are the main recognition components for brand users. It is undisputed psychological fact that customers' attitudes and brand perceptions do influence final behavior of customers towards firms' products and therefore overall success of companies on the market.

Conducted research of chosen Real Madrid brand provided results which prove that future club projections are based on strengthening of club brand by commercialization and investing to right players. Additional requirements for 
club's success are expansion of commercial activities from international perspective and by achieving a stable financial background. There are many brands with high value however not many of those brands are able to achieve successful status on the market. It is difficult to distinguish whether high income had created strong brands or already strong brand had been a driver behind high income. However, it is very clear that one relates to the other and both of those factors are co-influencing each other. The ability of Real Madrid brand to basically sell anything what is related to the club is main driving power behind high income. The clear parallel between high income and ability to increase the brand awareness has psychological effect on its fans and the whole market.

The best enlighten of income versus debt situation and its position towards profit is defined by general saying "Revenue is for vanity, profit is for sanity." At the end revenues or income look attractive in financial statements, however an ability of company to generate profit is the main attribute for any debt consolidation and overall financial stability.

\section{References}

Bourne, J. (2014). Which football clubs are top of the league in social and responsive design? [Online]. Available: http://www. marketingtechnews.net/news/2014/jun/10/which-football-clubs-are-top-league-social-and-responsive-design/ (juni 12, 2014)

Brand Finance. (2014). Global 500 2014. [Online]. Available: http://brandirectory.com/league_tables/table/ global-500-2014

Brand Finance. (2014). The Brand Finance Football 50 2014. [Online]. Available: http://brandirectory.com/league_tables/table /global$500-2014$

Brand Perfect Goal! (2014). A Brand Petrfect report analzsing the digital performance of some of the world's most successful association football clubs. [Online]. Available: http://brandperfect.org/goal/ (juni 12, 2014)

Deloitte. (2014). Football Money League 2014. All to play for Football Money League. Sports Business Group Deloitte, January 2014

Ditte, B. (2012). Futbalový raj na ostrove. Páni, tešte sa! [Online]. Available: http://cestovanie.aktuality.sk/ clanok/6124/futbalovy-raj-naostrove-pani-teste-sal (april 4, 2012)

Gonzalez-Barrera, A. - Lopez, M. H. (2013). Spanish is the most spoken non-English language in U.S. homes, even among nonHispanics. Fact Tank - Our Lives in Numbers. [Online]. Available: http://www.pewresearch.org/fact-tank/2013/08/13/spanish-isthe-most-spoken-non-english-language-in-u-s-homes-even-among-non-hispanics/ (august 8, 2013)

Keselak, T. (2010). Najpopulárnejším klubom Európy je FC Barcelona. [Online]. Available: http://m.wbn.sk/ sport/clanok/215998najpopularnejsim-klubom-Eurospy-je-fc-barcelona/ (september 9, 2010)

Madridismo. (2012). Photos of real madrid resort Island. [Online]. Available: http:// www.madridismo.org/photos/presentation-of-realmadrid-resort-island/?filter=real+madrid+ resort+island (march 22, 2012)

Mcdonald, M. - Mouncey, P. (2009). Marketing Accountability: How to Measure Marketing Effectiveness. London : Kogan Page, 2009. $304 \mathrm{p}$. .

My Marketing World. (2011). Real Madrid and F.C. Barcelona lead tambin social networks. 2011 [Online]. Available: http:/l mymarketingworld.blogspot.sk/2011/08/real-madrid-and-fc-barcelona-lead.html (august 3, 2011)

Ohim. (2013). Real Madrid club de futbol. [online]. Alicante : Office for Harmonization in the Internal Market. [Online]. Available: http://esearch.oami.Eurospa.eu/copla/applicant/data/25900

Olins, W. (2009). O značkách. Praha : Argo, 2009. 253 p.

Príbová, M. - Mynárová, L. - Hindls, R. - Hronová, S. (2000). Strategie řizení značky - Brand management. Praha : Ekopress, 2000. 148 p.

Real Madrid buang tanda salib pada logo. (2012). [Online]. Available: http://www.sufferedge.my/2012/04/real-madrid-buang-tanda-salibpada-logo.html (april 15, 2012)

Real Madrid Football Club Logo History. (2014). [Online]. Available: http://www.soccermaniak.com/real-madrid-logo.html, http://www. logo-designer.co/concept-rebrand-for-real-madrid-football-club/ (april 30, 2014)

Real Madrid News. (2013). Cristianoo Ronaldo's shirt: Real Madrid deal of the century. [Online]. Available: http://news-realmadridfootball.blogspot.com/2013/03/Cristianoo-ronaldos-shirt-real-madrid.html (march 10, 2013)

Realmadrid. (2012). Annual Report 11/12. 2012 [Online]. Madrid : Real Madrid Club de Fútbol. Available: http://www.realmadrid. com/StaticFiles/RealMadrid/img/pdf/M_Rm_InfomeAnual_11-12_Ingles_web_161012.pdf

Realmadrid. (2010). Informe Anual 09/10. 2010 [Online]. Madrid : Real Madrid Club de Fútbol. Available: http://www.realmadrid. com/StaticFiles/RealMadrid/img/pdf/InformeRm09_10.pdf

Sasko, J. (2010). Hodnota značky alebo prečo treba budovat' dobré meno. 2010. Bratislava : VISIBILITY s.r.o.

Soccerbible. (2012). Most Expensive Football Transfers Ever. 2012 [Online]. Updated Available: http://www.soccerbible.com/ news/general/archive/2012/08/30/most-expensive-football-transfers-ever.aspx (augustl 30, 2012)

Szabo, Z. K. - Šoltés, M. - Herman, E. (2013). Innovative Capacity and Performance of Transition Economies: Comparative Study at the Level of Enterprises In: E+M Ekonomie a Management. 2013, Vol. 16, Iss. 1, p. 52-68.

Transfermarkt. (2013). Real Madrid Transfers. 2013 [Online]. Available: http:// www.transfermarkt.co.uk/en/real-madrid/transfers/ verein_418.html (april 4, 2013)

Valiovský, J. (2012). Psychologické aspekty významu značky v marketingovej komunikácii. Bakalárska práca. TU Košice, 2012. 58 p.

Vejačka, M. (2012). Facebook Advertising and its Efficiency on the Slovak Market. In: E+M Ekonomie a Management. 2012, Vol. 15, Iss. 1, p. 116-127. 